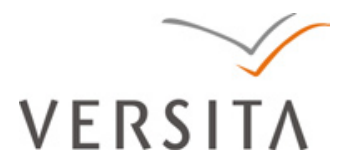

Folia Oeconomica Stetinensia

DOI: $10.2478 /$ foli-2013-0007

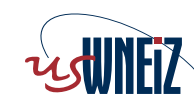

Wydzial Nauk Ekonomicznych i Zarządzania
Uniwersytetu Szczecińskiego

\title{
STRUCTURE OF A DECISION SUPPORT SUBSYSTEM \\ IN REAL ESTATE MANAGEMENT
}

\author{
Małgorzata Renigier-Biłozor, Ph.D. \\ University of Warmia and Mazury in Olsztyn, Poland \\ Faculty of Geodesy and Land Management \\ Department of Real Estate Management and Regional Development \\ Prawochenskiego 15 Str., 10-724 Olsztyn, Poland \\ e-mail: malgorzata.renigier@uwm.edu.pl
}

Received 13 May 2013, Accepted 12 November 2013

\begin{abstract}
This study proposes a decision support subsystem in real estate management. Owing to the complex and multi-layered character of the discussed problem, only selected aspects of real estate management are discussed in this paper. The described system will play the role of a relatively simple and effective "assistant" which is expected to maximize the effectiveness of a decision and shorten decision-making time. The author has made an attempt to develop a subsystem as an adviser to subjects operating in the real estate management. This system was developed accounting for and combining the classical economic and real estate market theories with the implementation of non-classical methods in the data mining category in an effort to increase its effectiveness. The rough set theory has been proposed as a tool that supports analytical processes. Fuzzy logic best reproduces expert knowledge, and it is one of the most effective tools for solving "vaguely defined" problems.

The given work is an attempt to prove the hypothesis that: the reduction of uncertainty in the real estate management decision-making process is possible by the development of the advisory system based on the rough set theory. The main aim of this work is to increase the efficiency and efficacy of entities operating in the real estate management, thus influencing the effectivness of the entity and management.
\end{abstract}

Keywords: decision support subsystem, real estate management, rough set theory.

JEL classification: C19, O18, R31. 


\section{Introduction}

Procedures and decisions in the area of real estate management require an objective approach. This assumption, which is rooted in legislative provisions and occupational standards, is rarely fully realized in practice. Every decision relating to real estate valuation, forecasting the consequences of changes in local zoning plans or the local real estate market, is characterized by subjectivity. Subjective decisions obstruct the adoption of uniform and stable evaluation criteria in the decision-making process.

Although recent year have witnessed the growing popularity of various support systems, comprehensive and effective information systems that facilitate real estate management and analyses continue to be in short supply. The above results from the specific character of real estate management operations which involve complex procedures and decisions, as well as the unique character of real estate data. Those factors prevent smooth flow of information which is required for the implementation of rational decisions and actions in business, investment, financial and promotional projects.

One from the most important reasons behind undertaking research in this area is the problem which occurs in the advanced real estate analysis, such as an object of appraisal and management and allocation to specific purposes. The main problem involves the selection and application of appropriate analytical research methods and procedures, which would be relevant to the specificity of information related to the real estate market and create a kind of coherent system aiding the decision-making process.

The work is an attempt to prove the hypothesis that: reducing uncertainty in the real estate management decision-making process is possible by developing an advisory system based on the rough set theory. The main aim of this work is to increase the efficiency and efficacy of entities operating in real estate management, and thus influence the effectiveness of the entity and management. Moreover the aim of developing the above mentioned support subsystem is to include the systematization and unification of information necessary into a given issue. It is designed to sufficiently simplify the complexity of the problem so that it can be used, implemented and interpreted by a wide range of users.

\section{Material and methods}

A method based on the rough set theory and fuzzy logic accounts for the specific character of information relating to the property market. The rough set theory, formulated by Polish mathematician, Professor Zdzisław Pawlak, is applied to process imprecise, vague 
and uncertain knowledge in data analyses ${ }^{1}$. The above features are characteristic of real estate market information, and they have to be taken into account when "vague" decisions are made in the area of real estate management. As an important tool in the data mining process, the rough set theory is one of the fastest growing fields in artificial intelligence research. It offers a formal, logical-set theory approach to knowledge processing and formulating conclusions about objects. Rough sets are used to exploit the database knowledge, which is an iterative and interactive process (where many decisions are made by the user). Although it is a relatively new concept, the rough set theory has growing number of applications in various fields of science, including medicine, pharmacology, economy, banking, chemistry, sociology, acoustics, linguistics, general engineering, neural engineering and machine diagnostics ${ }^{2}$. In recent years, several attempts have also been made to apply the rough set theory in spatial management ${ }^{3}$. The discussed method offers a robust theoretical basis for solving problems in intelligent decision systems.

\section{Decision-making process - discussion}

The objective of the decision theory is to provide detailed information for the decisionmaking process ${ }^{4}$. Mathematical, statistical and scientific methods are used to forecast changes in the environment, to predict and evaluate multivariate outcomes of actions. According to the cited authors, the decision theory has the following characteristic features:

1. Orientation on decision-making. The end result is information that facilitates the decision-making process.

2. Use of a scientific method. The decision theory aims to: identify the problem, identify the system where the problem exists, propose solutions that can or cannot be implemented,

3. Economic effectiveness. Anticipated benefits - profits should outweigh costs.

4. Use of a mathematical model. A mathematical approach should be used to model reality.

5. Use of a computer. Computers are supporting tools, they should not replace decision makers.

6. Team effort. Complex problems should be solved by a team of experts.

7. A system-oriented approach. Optimal solutions should be generated for the system rather than for its individual components. 
The decision theory facilitates decision-making, shortens decision-making time, delivers greater accuracy in problem analysis, maximizes the effectiveness of initiated actions and, consequently, the effectiveness of the decision. Its greatest weaknesses include high implementation costs, hardware and software limitations, such as computers and applications required for specialist calculations, lack of options for eliminating human participation in the decision-making process, and the need to develop algorithms at every stage of the decisionmaking and problem-solving process.

Decisions are made by analyzing information that is available for a given problem and selecting the best alternative for further action. Rao quotes Samuel Butler, who said: "Life is the art of drawing sufficient conclusions from insufficient premises", to indicate that decisionmaking involves uncertainty and the risk of error ${ }^{5}$. In theory, every decision has a $50 \%$ chance of success and an equal chance of failure. It could, therefore, be argued that a mistake could be avoided in $100 \%$ if no decisions were made. This, however, hampers development. Many decision makers face such an alternative when they are charged with responsibility for their actions and the resulting consequences. In line with the Chinese saying: "To guess is cheap, to guess wrong is expensive", efforts should be made to maximize the probability that the most appropriate decision is made.

The effectiveness of the decision-making process is determined by the availability of sufficient quantities of high-quality information relating to endogenous and exogenous aspects of the analyzed problem, the required level of competence on behalf of decision makers and supporting personnel (subcontractors), appropriate technical and financial resources (computers, databases) and decision-support tools (dedicated decision-support systems).

According to Knosala (2005), the decision-making process should aim to objectivize the decision by eliminating subjective factors ${ }^{6}$. As part of this process, the nature of the decisionmaking situation is analyzed, alternative solutions are identified, the optimal solution is selected and implemented ${ }^{7}$. According to the above author, the optimal solution is the most effective decision which, however, requires in-depth understanding of the specific decision-making context. The decision-making process can involve two types of reasoning: deductive, where a conclusion is reached based on the existing premises, and inductive, where the set of premises for formulating a conclusion is incomplete.

Comprehensive information is rarely available on the real estate market, and most decisions are made under uncertainty. By identifying the degree of uncertainty, we can develop methods that limit, control and account for uncertainty in the decision-making process ${ }^{8}$. For this 
reason, market analyses require solutions and methods that reflect reality, account for and, most importantly, minimize the degree of uncertainty.

\section{Support system for real estate management - results}

The decisions made in real estate management are generally characterized by a certain degree of uncertainty. We should be able to determine whether the relevant decision is burdened by risk or uncertainty. In view of the specific features of real estate, the long life span of property and the relative unpredictability of the real estate market environment, most decisions on the real estate market are made under uncertainty. Since uncertainty and risk cannot be completely eliminated, the decision-making process should be structured in such a way as to minimize those factors. This goal can be achieved by increasing access to information and programming simulations of decision-making variants. The scope and scale of uncertainty is, therefore, determined by access to information and the quality of that information (Figure 1).

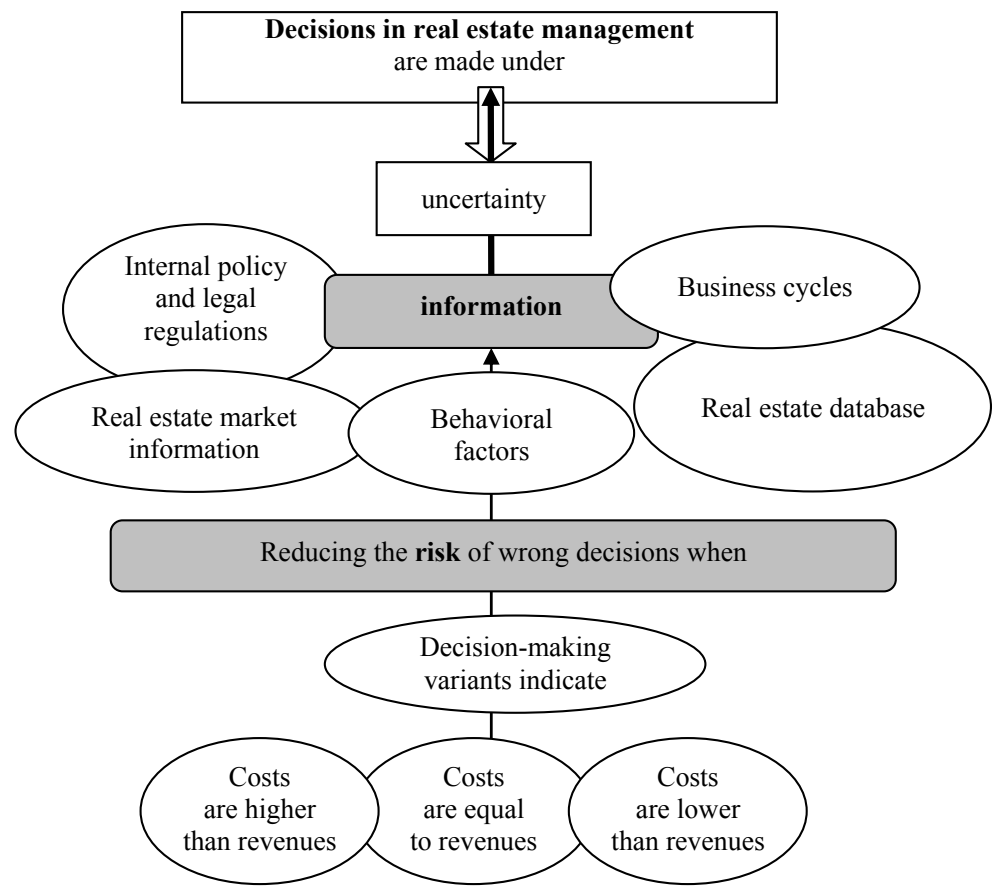

Fig. 1. Decisions in real estate management and information resources

Source: own work. 
In Figure 1, we made the assumption that uncertainty in real estate management is influenced by the complexity and unpredictability of information which is available to decision makers, including legal, technical, economic and financial requirements as well as behavioral factors that are responsible for the unpredictability of human decisions. Real estate decisions are highly complex and burdened by significant uncertainty, especially when they are made by public administration authorities, including at the municipal level. The risk of wrong decisions and the degree of uncertainty can be reduced through precise formulation of goals. Figure 1 proposes three variants for attaining goals. The variant in which costs are expected to top revenues may seem to be controversial, yet in view of the long life span and high costintensiveness of real estate, this variant may generate positive effects when applied over a short period of time. According to Knosala, decisions made by public administration authorities should be particularly well thought out because they concern public resources ${ }^{9}$.

Real estate management is a continuous decision-making process which requires adequately prepared and developed information. This process involves a number of popular decision-making techniques. Simon distinguishes between traditional and modern decisionmaking methods ${ }^{10}$. Traditional techniques include habit, office routine - standard procedures, organizational structure - shared expectations, a system of lower-order goals, judgment intuition and creativity, work rules, employee selection and training. According to Simon, the set of modern methods accounts for operational research - mathematical analysis, computer models and simulations, data processing, heuristic techniques - training decision makers and heuristic programming. The above methods support the development and refinement of decision support systems. According to Zieliński, the following types of information systems have practical applications ${ }^{11}$ :

- transaction processing systems (TPS),

- office automation systems (OAS),

- management information systems (MIS),

- decision support systems (DSS),

- executive support systems (ESS),

- expert systems (ES).

The above systems:

- support semi-structured or weakly structured decisions,

- are designed for individuals or groups of decision makers at various levels of management,

- support interdependent and/or sequential decisions, 
- support every stage of the decision-making process, various processes and procedures,

- are easy to use and develop,

- produce faster decisions of higher quality and greater accuracy, but they do not replace the decision maker,

- enable the decision maker to control every stage of the process,

- enable users to acquire new experience.

The first decision support (DSS) and expert systems (ES) were developed in the early 1970s, and they are considered to be the most appropriate methods for making decisions in the area of real estate management under uncertainty. Those methods account for endogenous and exogenous factors in real estate management, and they effectively solve "vaguely defined" problems ${ }^{12}$. DSS and ES are computer applications which provide users in weakly-structured decision contexts with information, access to analytical decision models and databases ${ }^{13}$. DSS rely on standard or expert solutions, and they can be deployed to solve highly complex problems.

DSS require specific hardware solutions as well as specialist components that support prognostic and decision-making functions. They comprise databases, sub-systems for database management, model databases and sub-systems for their management, as well as a subsystem that supports user-system communication. According to Stoner and Wankel, one of the greatest advantages of DSS is that it supports manipulation of data acquired directly from the central system as well as from memory ${ }^{14}$.

Expert systems are computer programs that rely on professional knowledge to provide experts with support in the process of solving highly complex problems. According to Rutkowski, expert systems are "intelligent" programs that apply knowledge and logical reasoning to solve problems that require human experience which has been accumulated over many years ${ }^{15}$. This is how the knowledge acquisition process is described by Mulawka ${ }^{16}$ : a knowledge engineer acquires information from an expert, the engineer solicits the expert's support if needed, and the acquired knowledge - a set of rules describing relations between facts - is encoded in the knowledge database. Reasoning, a process of matching facts with assumptions, activates the rules.

\section{Supporting selected decision-making procedures in real estate management - results}

A decision is the result of the exchange of information between various entities which contribute new arguments and preferences to the process. The decision-making process involves 
guidelines and authorization, and it falls subject to rigorous legal provisions and restrictions in the real estate market (in particular as regards public owners). The decision-making process comprises the following stages ${ }^{17}$ : definition of a decision-making problem, system of goals, decision alternatives, decision-making limitations, choice of decision, implementation and control.

A decision-making procedure that has been modified for the needs of the real estate market is presented in Diagram 1. Its structure has been designed in view of specific problems as well as decision algorithms that had been developed for the real estate market in the author's previous studies based on the rough set theory ${ }^{18}$. The factors describing the analyzed objects (real estate) and decision alternatives have been selected in view of the application possibilities of the method based on the rough set theory. The proposed structure of the decision-making procedure accounts for a number of important factors. The decision-making process in real estate management comprises the following stages (Diagram 1a and $1 \mathrm{~b}$ ):

1) determination of the objective of the decision-making process,

2) determination of goals,

3) identification of factors that directly influence decisions,

4) identification of decision alternatives,

5) identification of decision constraints, choice of decision.

Ad. 1. Decision-making problem. This stage involves the definition of the problem which underlies the decision-making process, as well as other areas of interest and conflict. As regards public property and, in many cases, also private property, a conflict of interest exists between non-profit activities, social interests and profit-oriented activities. In the context of managing public property, the objective of the decision-making problem is difficult to define due to excessive bureaucracy and administrative procedures that often analyze the issue outside of its natural social and business environment.

In the diagram, this stage is illustrated on the example of selected problems in real estate management. They are of strategic importance for both public and private owners, including: the profitability of investment in infrastructure development and real estate division, efficiency of the real estate market, real estate transactions and functions of real estate.

Ad. 2. Every decision aims to achieve a specific goal. Goals are selected in view of the existing norms and optimization criteria. Goals should be rationally defined, they should be complete, transparent and consistent with the owner's policy. In this phase, factors that could affect the decision should be clearly defined over a specific time horizon, and the correlations between those factors should be described. 
On the market of public real estate, goals are often superimposed, and decision makers' choices are limited by legal norms, internal standards of an administrative unit, resource management plans, social approval and the needs to protect the interest of the local community. The objectives of policies aiming to manage municipal real estate have to be consistent with the expectations of the local residents, the strategies of the local government and the state. In this context, strategic aims have to be reconciled with decision-making objectives, preferably in quantitative terms, such as the financial rationale for infrastructure development and real estate division (e.g. costs can exceed revenues by $30 \%$ ) or plans to sell more real estate (e.g. minimum $15 \%$ of local resources).

Ad. 3. Direct factors that could affect decisions and performance should be identified at the stage of analyzing the available resources, including material resources, such as hardware, financial resources, personnel availability and qualifications.

There is a broad range of factors that support the rationalization of the decision-making process in real estate management. Owing to their qualitative and quantitative variation as well as dynamic changes in the environment, the number of such factors should be narrowed down to reduce data acquisition costs and guarantee data stability (or minimize its variation) over a short period of time. To maximize the legibility and usefulness of the discussed factors, the range of information has been limited (Diagram 1). The factors considered in the decision-making process have been identified based on endogenous legal and financial indicators which are of key significance for the analyzed problem. The above measures have been introduced on the assumption that exogenous factors, such as business cycles, the owner's financial situation and legal considerations which have not been taken into account in developing the algorithm at this stage of the procedure, will be analyzed by decision makers. It should also be noted that selected endogenous factors, including the price of real estate, are indirectly dependent on exogenous factors. A longer time period and a larger the data set will produce more accurate results, but the decision-making procedure will also be more costly and time consuming.

Ad. 4. In reference to the real estate market, decision alternatives generally rely on multiple criteria. The alternatives supporting the achievement of a specific goal are selected by evaluating their possible consequences and by correlating them with the available resources, the time horizon and the owner's intentions and plans, in particular long-term plans. On the real estate market, decision alternatives are often superimposed due to their unique character. The presented structure proposes the following alternatives: function of real estate, real estate management, efficiency of the real estate market and the estimated value of real estate. 
Ad. 5. Decision constraints include factors of legal, financial, ethical and political nature. Those factors may be rejected or modified by decision makers. Decision constraints are encountered at every stage of the decision-making process. As regards the management of municipal real estate, the key constraints are of legal nature, followed by endogenous factors, such as the economic situation, business cycles, the owner's financial standing and resource availability. Legal regulations constitute the venture point for formulating the goal, in particular in the process of managing public property. Legal provisions act as guidelines in the process of setting objectives, and they often dictate the form and scope of the relevant decisions. Conditional decisions are an example of the above.

Rational decisions are made by integrating all stages of the decision-making process which may involve a feedback mechanism. The return to previous sequences could result from errors, which are only manifested at successive stages of the process, including a shortage of data, incorrect description of data or modification of process stages due to excessive variations in the analyzed factors, such as time trends.

In the below diagram, the feedback mechanism has been emphasized to ensure greater transparency of the decision-making process, including the selection of alternatives and final decisions. The available options should be analyzed carefully at this stage. After the decision has been implemented, the relevant procedure should be controlled, evaluated and verified at successive stages of the decision-making process.

\section{Case study which demonstrates the application methodology of the rough set theory (RST) in decision-making procedures in real estate management}

The objective of this work was to select a method for evaluating the influence of property attributes which most effectively determine the choice of property functions with utilization of the rough set theory assumptions. In many spatial planning decisions, the distribution of various functions is often accidental due to the shortage of land in urban areas, an absence of compulsory purchase laws or pressure exerted by developers on property owners. In the analyzed example, the choice of real estate functions was determined in view of the existing resources rather than the principles of rational real estate management or sustainable development goals. The real estate function was not optimized in view of property prices, but it was chosen to best address the existing market situation and provide an important element of decision-making in the real estate management. 
The presented analysis relies on the findings of M. Renigier-Biłozor and A. Biłozor ${ }^{19}$. This study analyzes the real estate market in the city of Olsztyn, NE Poland

The experimental material comprised a set of data from 120 land property transactions conducted in the Olsztyn area between January 2010 and October 2011. To investigate the effect that real estate attributes have on land function, each property was described with a minimal set of attributes which are usually taken into account by the local authorities to determine the manner of land use. Real estate prices, marked successively as $\mathbf{c}_{1}, \mathbf{c}_{2}, \mathbf{c}_{3}, \mathbf{c}_{\mathbf{4}}, \mathbf{c}_{5}, \mathbf{c}_{\mathbf{6}}$ (Table 1), are conditional attributes. Real estate function $\mathbf{d}$ is a decisional attribute.

Table 1. Conditional attributes and a decisional attribute applied in the study

\begin{tabular}{|c|c|c|c|c|c|c|}
\hline \multicolumn{6}{|c|}{ Conditional attributes } & Decisional attribute \\
\hline $\mathrm{c}_{1}$ & $\mathrm{c}_{2}$ & $\mathrm{c}_{3}$ & $\mathrm{c}_{4}$ & $\mathrm{c}_{5}$ & $\mathrm{c}_{6}$ & $\mathrm{~d}$ \\
\hline Area & Location & Utilities & Attractiveness & Accessibility & Price & Function \\
\hline
\end{tabular}

Source: own study.

The above attributes were evaluated on the following scale:

$\mathrm{c}_{1}$ - land area in $\mathrm{m}^{2}$,

$\mathrm{c}_{2}$ - location, encoded based on the following criteria: 1 - inconvenient, 2- average, 3 -convenient, 4 - highly convenient,

$\mathrm{c}_{3}$ - utilities supply, encoded based on the following criteria: 1 - none, 2 - partial supply, 3 - full supply,

$\mathrm{c}_{4}$ - attractiveness, encoded based on the following criteria: $1-$ low, 2 - average, 3 - high,

$\mathrm{c}_{5}$ - transport accessibility: 1 - poor, 2 - average, 3 - satisfactory, 4 - highly satisfactory,

$\mathrm{c}_{6}-$ price per $\mathrm{m}^{2}$ of land as in October 2008,

$\mathrm{d}$ - function, encoded based on the following criteria: 1 - single-family housing, 2-high-rise housing, 3-commercial, 4-transportation, 5-industrial, 6-recreational with development options, 7 - other, 8 - warehouses and storage facilities, 9 - health care facilities.

On the basis the above data used RST to determine the most important attributes. A generalized scheme (Figure 2) has been presented below which contain various stages of the procedure. Details can be found in the papers of M. Renigier-Bilozor and A.Bilozor ${ }^{20}$. The purpose of introducing a new method based on the RST for this problem of real estate is 
the ability to use a fast, reasonably simple procedure for determining significance of property attributes in the choice of property functions, e.g., on small real estate markets, where statistical analyses usually have low reliability.

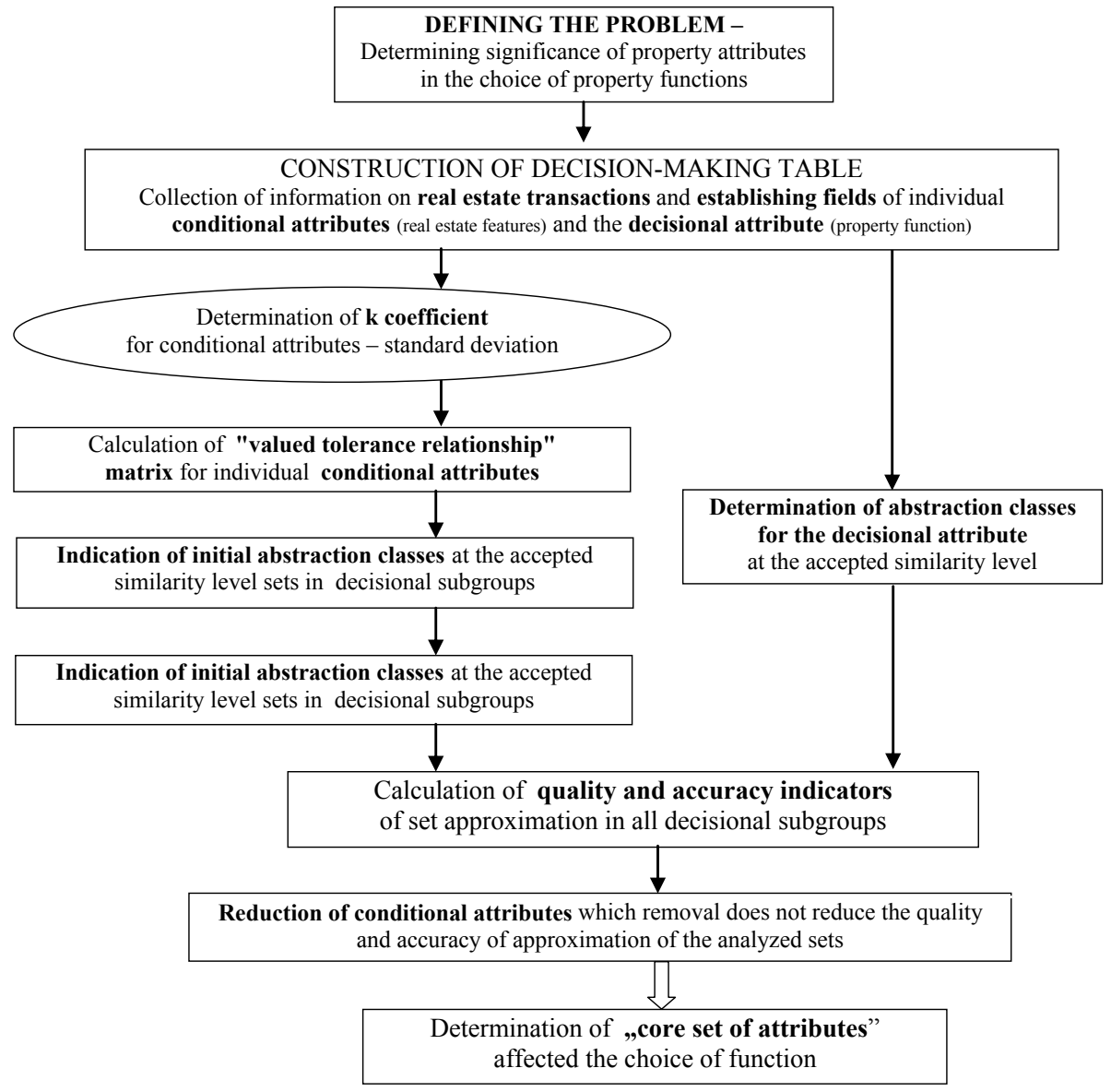

Fig. 2. Determination of significance of real estate attributes in determining land use functions with use of the rough set theory

Source: own study

The above results indicate that the choice of function is affected by attributes which, in line with the rough set theory, form a core of the attributes set, as illustrated by Table 2 (marked with a cross). 
Table 2. Core of decisional attributes

\begin{tabular}{|l|c|c|c|c|c|c|}
\cline { 2 - 7 } \multicolumn{1}{c|}{} & Area & Location & Utilities & Attractiveness & Accessibility & Price \\
\hline Decisional attribute No. 1 & $\mathrm{X}$ & $\mathrm{X}$ & & & $\mathrm{X}$ & $\mathrm{X}$ \\
\hline Decisional attribute No. 2 & $\mathrm{X}$ & $\mathrm{X}$ & $\mathrm{X}$ & $\mathrm{X}$ & $\mathrm{X}$ & $\mathrm{X}$ \\
\hline Decisional attribute No. 3 & $\mathrm{X}$ & $\mathrm{X}$ & $\mathrm{X}$ & & $\mathrm{X}$ & $\mathrm{X}$ \\
\hline Decisional attribute No. 4 & $\mathrm{X}$ & $\mathrm{X}$ & $\mathrm{X}$ & & $\mathrm{X}$ & \\
\hline Decisional attribute No. 5 & $\mathrm{X}$ & $\mathrm{X}$ & $\mathrm{X}$ & $\mathrm{X}$ & $\mathrm{X}$ & $\mathrm{X}$ \\
\hline Decisional attribute No. 6 & & $\mathrm{X}$ & $\mathrm{X}$ & & & \\
\hline Decisional attribute No. 7 & & $\mathrm{X}$ & $\mathrm{X}$ & & $\mathrm{X}$ & $\mathrm{X}$ \\
\hline Decisional attribute No. 8 & $\mathrm{X}$ & $\mathrm{X}$ & & & & $\mathrm{X}$ \\
\hline Decisional attribute No. 9* & - & - & - & - & - & - \\
\hline
\end{tabular}

* The results for decision attribute No. 9 were rejected - if any of the attributes are equal to zero, a given set is completely discernible, i.e. it corresponds to other decisional attributes. Decision No. 9 does not show any individual dependencies in relation to conditional attributes.

Source: own study.

The above results indicate which attributes contribute most to the choice of different property functions. In line with the rough set theory, the following attributes affected the choice of function for a given real estate set:

- single-family housing function - area, location, transport accessibility and price,

- high-rise housing function - area, location, utilities supply, attractiveness, transport accessibility and price,

- commercial function - area, location, utilities supply, transport accessibility and price,

- transportation function - area, location, utilities supply, transport accessibility,

- industrial function - area, location, utilities supply, attractiveness, transport accessibility and price,

- recreational function - location, utilities supply,

- other function - location, utilities supply, transport accessibility and price,

warehouses and storage facilities function - area, location and price.

The presented methodology for determining the effect of real estate attributes on the selection of the appropriate land use function significantly contributes to real market surveys. An analysis of real estate transactions generated a group of attributes which considerably affect the designation and, consequently, the value of property. The significance of each real estate attribute was assessed with the use of the rough set theory combined with the value tolerance relation.

According to the authors, popular analytical methods (mostly statistical) are relatively ineffective in weak-form efficient real estate markets. The preferred methods and procedures 
Table 3. The use of the rough set theory (rst)

for supporting selected decision-making procedures in real estate management

\begin{tabular}{|c|c|c|}
\hline \multicolumn{3}{|c|}{ RST-based methods for analyzing the real estate } \\
\hline general problem & detailed problem & solution \\
\hline $\begin{array}{l}\text { Selection of methods for managing } \\
\text { and using buildings and apartments } \\
\text { (Renigier, 2006) }\end{array}$ & $\begin{array}{l}\text { Analysis of the real estate market } \\
\text { using various methods for registering } \\
\text { real estate attributes without data loss } \\
\text { (Renigier, 2008) }\end{array}$ & $\begin{array}{l}\text { Option of analyzing data sets } \\
\text { without the risk of data loss when } \\
\text { quantitative attributes are replaced } \\
\text { with qualitative attributes }\end{array}$ \\
\hline $\begin{array}{l}\text { Real estate appraisal on markets } \\
\text { characterized by limited resource } \\
\text { availability (Renigier, 2008) }\end{array}$ & $\begin{array}{l}\text { Real estate appraisal involving } \\
\text { limited data sets (Renigier, 2008) }\end{array}$ & $\begin{array}{l}\text { Real estate appraisal based } \\
\text { on expert data sets, with high } \\
\text { confidence in results }\end{array}$ \\
\hline \multirow[t]{2}{*}{$\begin{array}{l}\text { Selection of functions assigned to } \\
\text { land on ineffective real estate markets } \\
\text { (Renigier-Biłozor, Biłozor 2009) }\end{array}$} & $\begin{array}{l}\text { Determining the significance of real } \\
\text { estate attributes without the use of } \\
\text { statistical methods (Renigier-Biłozor, } \\
\text { Biłozor 2009a, 2009b) }\end{array}$ & $\begin{array}{l}\text { Reliable verification of the } \\
\text { significance of attributes adopted } \\
\text { based on a limited data set }\end{array}$ \\
\hline & $\begin{array}{l}\text { Determining weighing factors for } \\
\text { real estate prices (Renigier-Biłozor, } \\
\text { Biłozor 2009b) }\end{array}$ & $\begin{array}{l}\text { Determining the significance } \\
\text { of attributes without the use of } \\
\text { statistical tests }\end{array}$ \\
\hline $\begin{array}{l}\text { Real estate appraisal based on limited } \\
\text { market data (Renigier-Biłozor, 2010) }\end{array}$ & $\begin{array}{l}\text { Supplementing the missing real estate } \\
\text { attributes (Renigier-Biłozor, 2010) }\end{array}$ & $\begin{array}{l}\text { Determining the value of the } \\
\text { missing real estate attributes based } \\
\text { on the analyzed data set }\end{array}$ \\
\hline $\begin{array}{l}\text { Analysis of real estate markets } \\
\text { (Renigier-Biłozor, 2011; Renigier- } \\
\text { Biłozor, Wiśniewski, 2012) }\end{array}$ & $\begin{array}{l}\text { Classifications of the real estate } \\
\text { market focus particularly on } \\
\text { information efficiency (Renigier- } \\
\text { Biłozor, 2011; Renigier-Biłozor, } \\
\text { Wiśniewski, 2012) }\end{array}$ & $\begin{array}{l}\text { Determining the efficiency of real } \\
\text { estate markets }\end{array}$ \\
\hline
\end{tabular}

Source: own research.

should account for the following defects in real estate data: absence of data, small number of transactions, significant variations in attribute coding, non-linear correlations between the analyzed data and the type of the underlying market. The applied methods should support market analysis at the potential (theoretical) and actual (applied) level. The below solutions (Table 3) that rely on the rough set theory may offer an effective alternative to popular analytical methods. References to detailed studies are indicated in parentheses.

\section{Conclusions}

The choice of measures and the assessment of future consequences are important elements of the decision-making process. Future events are difficult to define and evaluate, therefore, only approximate predictions can be made. A set of optimal criteria has to be formulated for the planned goal to be achieved. Quantitative methods can be used to facilitate the decision-making 
process, but they can never replace the decision maker. Public administration authorities can particularly benefit from quantitative methods which support the achievement of a compromise in a conflict situation.

In this study, an attempt was made to present the structure of a decision algorithm which facilitates the development of the decision support subsystem in real estate management. The system is a relatively simple and effective "assistant" which maximizes the effectiveness of a decision and shortens decision-making time. Presented solutions has been tested on the basis of the real estate from the resource of municipality Olsztyn during the implementation of the grant entitled: "Development of decision-making system using rough set theory on the real estate market". Presented system and proposed solutions through increasing access to information and improve decision-making which prove the hypothesis that: the reduction of uncertainty in the real estate management decision-making process is possible by the development of advisory system based on the rough set theory.

The structure of the subsystem presents some decision problems making are dealt with in the context of real estate management. Deliberately does not cover all issues in order to emphasize the fact that according to the authors specific structures and systems should not be developed in all areas of real estate management but only where it is especially necessary and useful. Ones in which access to information is difficult because of the dynamics of their changes, non-linear and even stochastic nature, which leads directly to the increased uncertainty in the real estate market were considered essential and making of risky decisions. However once the relevant information is obtained it becomes very important to select and combine methods which fit the specificity of the analyzed problem and phenomena.

Choosing even the most complex and sophisticated method, which doesn't take into account the nature of the area of study and specificity of the given data may lead to much greater negative consequences than the absence of applying method whatsoever. The use of the rough set theory as an analytical tool offers an alternative to conventional statistical analysis, and it creates a variety of application possibilities in the area of real estate management. 


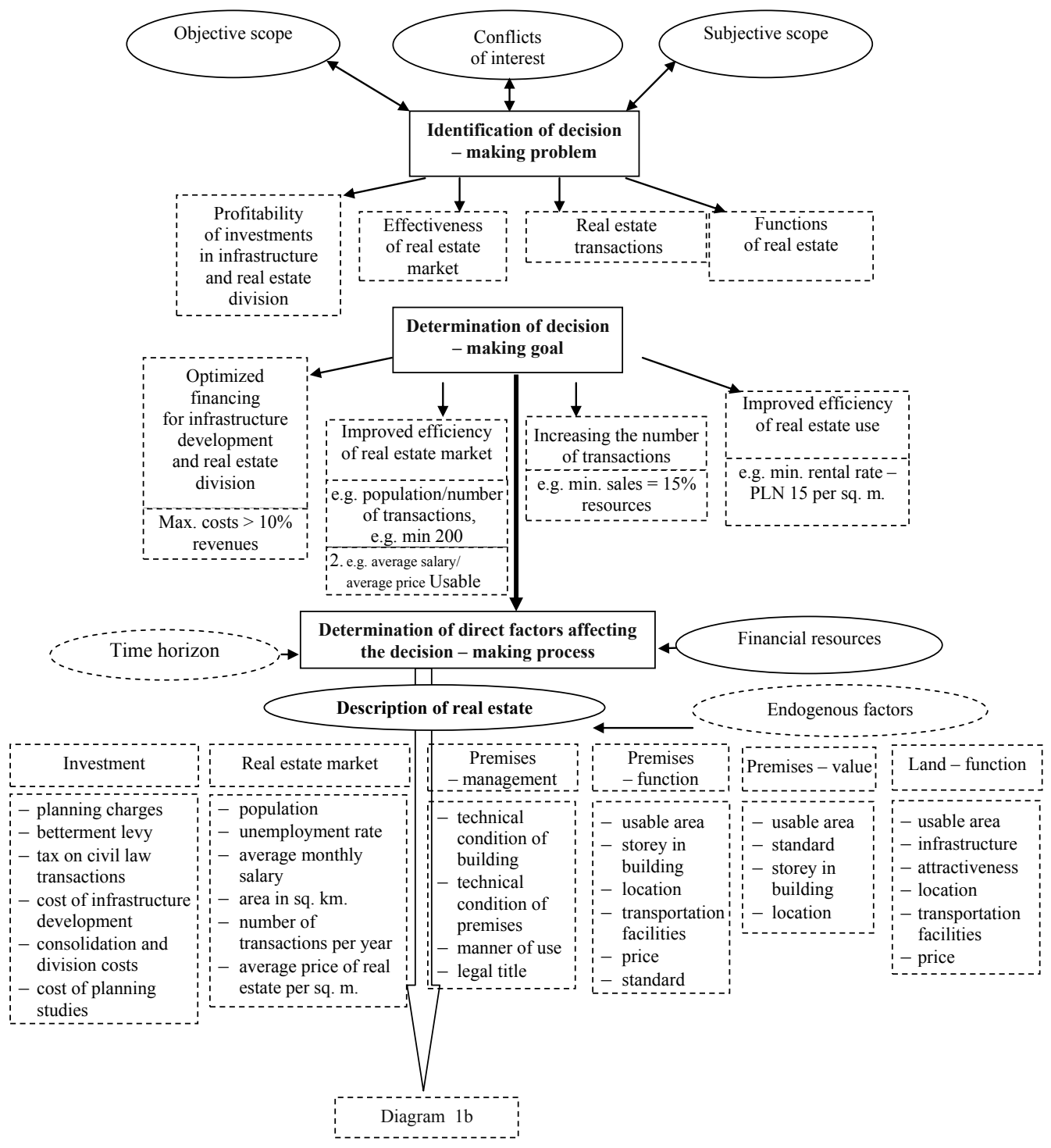

Diagram 1a. Structure of the decision-making process in real estate management as a feature of the decision support subsystem

Source: own work. 


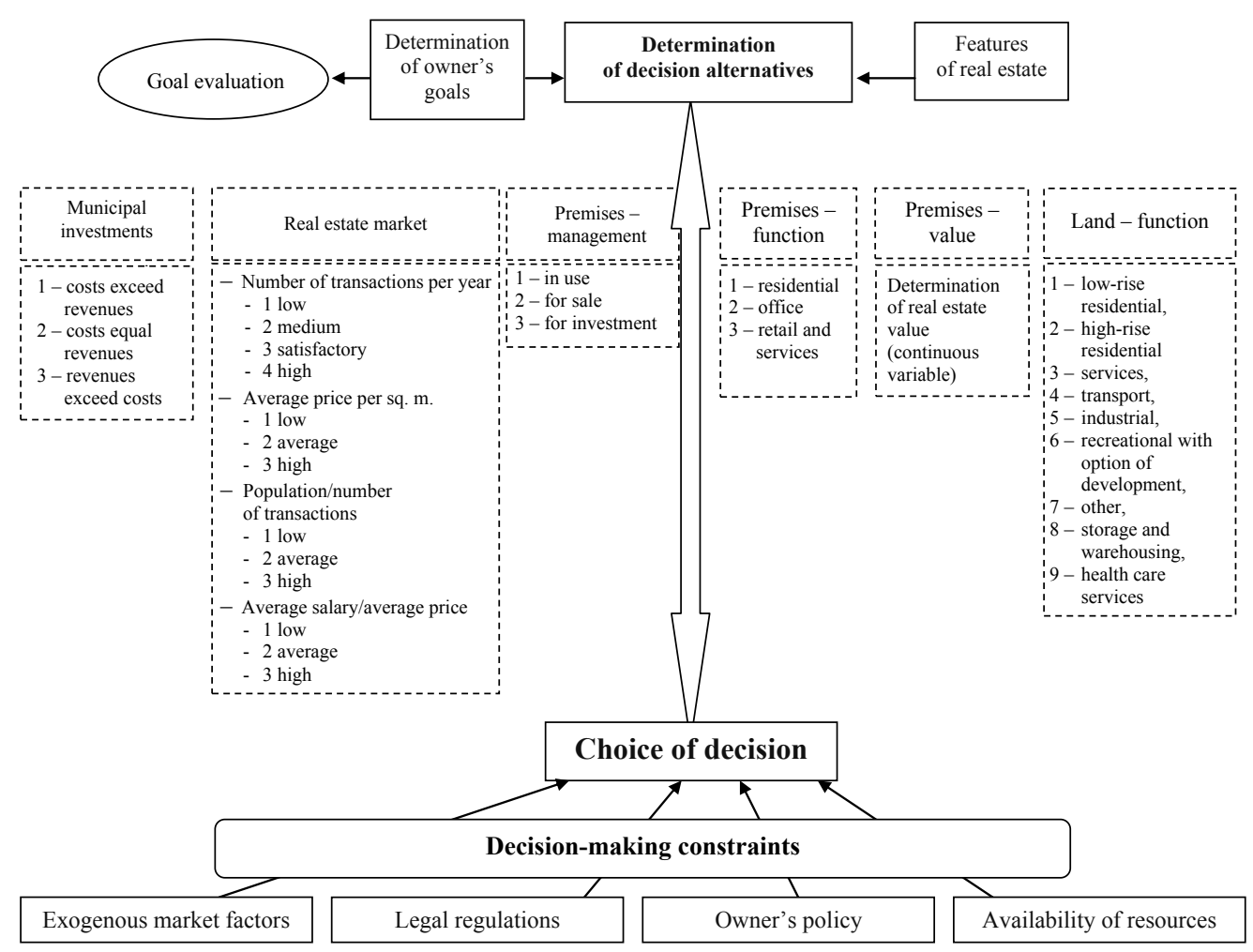

Diagram 1b. Structure of the decision-making process in real estate management as a feature of the decision support subsystem

Source: own work.

\section{Notes}

${ }^{1}$ Pawlak (1982, 1991, 1997).

${ }^{2}$ Deja (2000); Komorowski et al. (1999), pp. 3-98; Mrózek, Płonka (1999); Polkowski, Skowron (1998); Pawlak (1997); Nowicki (2009); Nutech Solution (2005); Słowiński (1992).

${ }^{3}$ d'Amato (2004, 2007); Kotkowski, Ratajczak (2002), pp. 35-44; Renigier-Biłozor (2006, 2008, 2010, 2011); Renigier-Biłozor, Biłozor (2008), p. 49; Renigier-Biłozor, Wiśniewski (2011).

${ }^{4}$ Stoner, Wankel (1994).

${ }^{5}$ Rao (1994).

${ }^{6}$ Knosala (2005).

7 Griffin (2000).

${ }^{8}$ Rao (1994).

${ }^{9}$ Knosala (2005).

${ }^{10}$ Simon (1997). 
${ }^{11}$ Zieliński (2000).

${ }^{12}$ Ibidem.

${ }^{13}$ Stoner, Wankel (1994); Wang (2005); Zieliński (2000).

${ }^{14}$ Stoner, Wankel (1994).

${ }^{15}$ Rutkowski (2009).

${ }^{16}$ Mulawka (1997).

${ }_{17}$ Knosala (2005); Szapiro (2000); Wiśniewski (2008); Zieliński (2000); Wiśniewski 2008.

${ }_{18}$ Reniger-Biłozor (2006, 2008, 2011); Reniger-Biłozor, Biłozor (2009a, 2009b).

${ }^{19}$ Renigier-Biłozor, Biłozor (2009a, 2009b).

${ }^{20}$ Ibidem.

\section{References}

d'Amato, M. (2004). A comparison between MRA and Rough Set Theory for mass appraisal. A case in Bari. International Journal of Strategic Property Management, 8 (4).

d'Amato, M. (2007). Comparing Rough Set Theory with Multiple Regression Analysis as Automated Valuation Methodologies. International Real Estate Review, 2.

Deja, R. (2000). Zastosowanie teorii zbiorów przybliżonych $w$ analizie konfliktów. Praca doktorska. Instytut Podstaw Informatyki Polskiej Akademii Nauk.

Griffin, R.W. (2000). Podstawy zarządzania organizacjami. Warszawa: Wydawnictwo Naukowe PWN.

Knosala, E. (2005). Zarys nauki administracji. Zakamycze: Kantor wydawniczy.

Komorowski, J., Pawlak, Z., Polkowski, L. \& Skowron, A. (1999). Rough sets: A tutorial. In: S.K. Pal \& A. Skowron (Eds.), Rough fuzzy hybridization: A new trend in decision making. Singapore: Springer-Verlag.

Kotkowski, B. \& Ratajczak, W. (2002). Zbiory przybliżone w analizie danych geograficznych. In: H. Rogacki (Ed.), Możliwości i ograniczenia zastosowań metod badawczych w geografii społeczno-ekonomicznej i gospodarce przestrzennej. Poznań: Bogucki Wydawnictwo Naukowe.

Mrózek, A. \& Płonka, L. (1999). Analiza danych metoda zbiorów przybliżonych. Warszawa: Akademicka Oficyna Wydawnicza PLJ.

Mulawka, J.J. (1997., Systemy ekspertowe. Wydawnictwa Naukowo Techniczne, Styczeń.

Nowicki, R.K. (2009). Rozmyte systemy decyzyjne w zadaniach z ograniczona wiedza. Warszawa: Akademicka Oficyna Wydawnicza EXIT.

Nutech Solution - science for businnes (2005), www.nutechsolutions.com.pl. 
Pawlak, Z. (1982). Rough sets. International Journal of Information and Computer Science 11: 341.

Pawlak, Z. (1991). Rough Sets: Theoretical Aspects of Reasoning abaut Data. Dordrecht: Kluwer Academic Press.

Pawlak, Z. (1997). Rough Sets and their Applications. Seminar Department of Computing Macquarie University.

Polkowski, L. \& Skowron, A., (Eds.) (1998). Rough Sets in Knowledge Discovery 1: Methodology and Applications, Physica-Verlag, Heidelberg.

Rao, C.R. (1994). Statystyka i prawda. Warszawa: PWN.

Renigier-Biłozor, M. (2006). Zastosowanie analizy danych metoda zbiorów przybliżonych do zarzadzania zasobami nieruchomości. Elbląg: Studia i Materiały Towarzystwa Naukowego Nieruchomości Vol. 14 (1): 219-232.

Renigier-Biłozor, M. (2008). Zastosowanie teorii zbiorów przybliżonych do masowej wyceny nieruchomości na małych rynkach. [Application of rough sets theory for mass valuation of real estate in small markets]. Acta Scientarum Polonorum Locorum, Administratio Locorum 7 (3): 35-51.

Renigier-Biłozor, M. (2010), Supplementing incomplete databases on the real estate market with the use of the rough set theory. Acta Scientarum Polonorum Locorum, Administratio Locorum 9 (4): 107-115.

Renigier-Biłozor, M. (2011). Analysis of real estate markets with the use of the rough set theory. Journal of the Polish real estate scientific society, 19, 3: 107-118.

Renigier-Biłozor M. \& Biłozor A. (2008). Aspekty i możliwości zastosowań teorii zbiorów przybliżonych i teorii zbiorów rozmytych $w$ gospodarce przestrzennej. In: Nowe kierunki i metody $w$ analizie regionalnej. Poznań.

Renigier-Biłozor M. \& Biłozor A. (2009a). The significance of real estate attributes in the process of determining land function with the use of the rough set theory. Studia i Materiałay Towarzystwa Naukowego Nieruchomości. Olsztyn: 103-107.

Renigier-Biłozor, M. \& Biłozor ,A. (2009b). Procedura określania istotności wpływu atrybutów nieruchomości z wykorzystaniem teorii zbiorów przybliżonych. Przegląd Geodezyjny 6: 3-7.

Renigier-Biłozor, M. \& Wiśniewski, R. (2011). The efficiency of selected real estate markets in Poland Acta Scientiarum Polonorum, Oeconomia 9 (2): 83-96.

Renigier-Biłozor, M., Wiśniewski, R (2012). The Effectiveness of Real Estate Market Participants. European Spatial Research and Policy19 (1): 95-110.

Rutkowski, L. (2009). Metody i techniki sztucznej inteligencji. Warszawa: Wydawnictwo Naukowe PWN.

Simon, H. (1997). The New Science of Managenet deccision. Englewood Cliffs N.J. 
Słowiński, R. (1992). Intelligent Decision Support. Handbook of Applications and Advances of the Rough Sets Theory. Dordrecht: Kluwer Academic Publishers.

Stoner, J.A.F. \& Wankel, Ch. (1994). Kierowanie. Warszawa: Państwowe Wydawnictwo Ekonomiczne.

Szapiro, T. (2000). Decyzje menedżerskie z Excelem. Warszawa: Polskie Wydawnictwo Ekonomiczne.

Wang, W.K. (2005). A knowledge-based decision support system for measuring the performance of government real estate investment. Expert Systems with Applications 29 (2005): 901-912.

Wiśniewski R. (2008). Multidimensional forecasting of the value of a real estate. Dissertations and Monographs No. 124, UWM.

Zieliński, J. (2000). Inteligentne systemy $w$ zarządzaniu. Teoria i praktyka. Warszawa: Wydawnictwo Naukowe PWN. 